\title{
Movimentos de Colaboração Metodologia da Pesquisa Colaborativa
}

Adriana Fatima de Souza Miola Patrícia Sandalo Pereira

\section{Resumo}

Este artigo tem como objetivo compreender os movimentos de colaboração em uma proposta de formação continuada desenvolvida com a metodologia da pesquisa colaborativa. Os dados foram coletados durante o projeto em rede "Trabalho colaborativo com professores que ensinam Matemática na Educação Básica em escolas públicas das regiões Nordeste e Centro-Oeste", vinculado ao Programa Observatório da Educação (OBEDUC), realizado no Núcleo da Universidade Federal de Mato Grosso do Sul (UFMS). Esta investigação está fundamentada na Teoria Histórico-Cultural, pautada em estudos de Vygotsky e utilizou, como metodologia, a pesquisa colaborativa, segundo Ibiapina. O trabalho envolveu pesquisadores em Educação Matemática e professores e futuros professores de Matemática da Educação Básica. Dentre os resultados, destacamos que a proposta de formação continuada realizada na perspectiva da colaboração, utilizando a metodologia da pesquisa colaborativa e os seus procedimentos, mostrou-se como opção de pesquisa e formação, a qual propiciou coprodução de saberes e colaboração entre os participantes.

PalaVRas-ChaVe: Educação Matemática, Formação Continuada, Pesquisa Colaborativa, Colaboração. 


\title{
Collaboration Movements from the Collaborative Research Methodology
}

\author{
Adriana Fatima de Souza Miola \\ Patrícia Sandalo Pereira
}

\begin{abstract}
This article aims to understand the collaboration movements in a proposal of continuous formation developed from the collaborative research methodology. Data were collected in the project "Collaborative work with teachers teaching Mathematics in Basic Education in public schools in the Northeast and Central West regions", linked to the Observatory of Education Program (OBEDUC), held at the Nucleus of the Federal Universityof Mato Grosso do Sul (UFMS). This research is guided by the Historical-Cultural Theory, based on Vygotsky studies and used, as methodology, the collaborative research, according to Ibiapina. The work involved researchers in Mathematics Education, teachers and future teachers of Mathematics of Basic Education. Among the results, we emphasize that the proposal of continuous training from the perspective of collaboration using the collaborative research methodology and its procedures, proved to be a possibility for research and training, which provided a co-production of knowledge and the collaboration between the participants.
\end{abstract}

Keywords: Mathematics Education, Continuous Formation, Collaborative Research, Collaboration. 


\section{Introdução}

A formação continuada de professores começou a institucionalizar-se no Brasil por volta de 1970, época em que predominavam propostas autoritárias, classistas, uniformizadoras e seletivas. Na década seguinte, as universidades criaram programas de formação continuada de professores em modalidades de treinamentos e de práticas, como, por exemplo, programas de minicursos, análise de competências técnicas, entre outros. Nos anos de 1990, começaram as preocupações sobre estudos teóricos e modelos alternativos de formações no âmbito das universidades, como o aparecimento de textos, comunicações, experiências, eventos, entre outros, como mostram os estudos de Imbernón (2010).

Esses estudos apontam que depois de 2000, surgiu a demanda de novas formas de ver a formação, o aluno e o papel do professor. Com isso, novos modelos de programas vinculados à prática da formação ganharam espaço. Então, não se analisa mais a formação somente como domínio de conteúdo, mas o que se aprende e o que falta aprender. Em meio a essas mudanças, muitos autores, como Nóvoa (1991), Abrantes e Ponte (1982), Demailly (1992), Candau (1997), entre outros, embora apresentem compreensões distintas sobre a formação continuada, possuem alguns pontos em comum, sendo possível abstrair que todas essas definições consideram a formação continuada como um continuum.

Notamos também que elas convergem para a ideia do papel do professor como copartícipe do seu desenvolvimento profissional. Desse modo, busca-se um trabalho de formação continuada de caráter coletivo, na perspectiva colaborativa, em que os participantes podem refletir em equipe e encontrar soluções para as situações-problema do cotidiano da sala de aula, abandonando o caráter individualista atribuído à atuação docente há algumas décadas. Nesse sentido, muitos pesquisadores têm discutido, no campo da Educação Matemática, o conceito de colaboração.

Embora tenham existido grandes avanços nessa discussão, não há uma definição única para tal conceito. Sendo assim, realizamos um levantamento das pesquisas brasileiras, no Banco de Tese da Capes, com a palavra colaboração, desenvolvidas no campo da Educação Matemática, sobre a formação continuada de professores de Matemática no segundo semestre de 2017 e existe nos trabalhos de Traldi Junior (2006, p. 43), o entendimento de colaboração como algo que “[...] preocupa-se primeiramente com questões imediatas e práticas, excluindo pesquisa sistemática e crítica. A preocupação dos envolvidos é a de se manter um clima de camaradagem pessoal, mas que resista aos desafios profissionais”.

Campos (2007, p. 98) pontua que, na relação de “[...] colaboração forma-se um rico contexto de aprendizagem para os envolvidos, uma vez que o grupo tem a oportunidade de compartilhar um objetivo comum”. O trabalho colaborativo é tratado pela autora, "[...] como forma de organização de um grupo, caracterizado pelo respeito, confiança e autonomia, além 
de oferecer condições motivadoras, também contribui para o desenvolvimento de um rico ambiente de aprendizagem" (CAMPOS, 2007, p.97).

Costa (2011, p. 54) afirma que “[...] o trabalho colaborativo favorece a troca de experiências, a partilha do conhecimento e a produção de novos saberes, necessários à formação contínua do professor, a partir do estabelecimento de situações de diálogo e negociação”.

Órfão (2012) também aponta, em sua pesquisa, o fortalecimento dos laços de amizade que se revigoraram, reforçando ainda mais as características de um trabalho colaborativo. Ferreira (2003, p. 109), por sua vez, trabalhou com “[...] grupo colaborativo no sentido de comunidade de prática, com as características de participação voluntária, colaboração por um objetivo comum, participantes a vontade para se expressar, sem existir verdade ou orientação única”.

Os demais autores encontrados (FERREIRA, 2003; COELHO, 2010; GAMA, 2007; GRINKRAUT, 2009; PEREIRA, 2011; ANDRADE, 2012; ALBURQUERQUE, 2012; GOMES, 2014) não apresentam uma definição e tratam o tema a partir de outros pesquisadores, principalmente, Fiorentini (2004). Encontramos em estudos de Albuquerque (2012) traços de uma pesquisa do tipo colaborativa. Assim como Gomes (2014), que, para mobilizar a conversão catastrófica do grupo de professores de Matemática em formação inicial, assumiu a pesquisa-ação colaborativa como estratégia formativa. Nesses dois últimos casos, entendemos o termo "colaborativa" como uma abordagem da pesquisa qualitativa.

Os resultados dessas pesquisas apresentaram fortes indícios sobre a importância do trabalho colaborativo, ou grupo colaborativo, para promover a reflexão sobre a prática, a aprendizagem de saberes da docência e os indícios de mudanças na prática dos professores participantes. Nesse sentido, este artigo busca contribuir com essa discussão ao analisar os movimentos de colaboração em uma proposta de formação continuada desenvolvida por meio da metodologia da pesquisa colaborativa, em que partimos da necessidade dos professores participantes, pois notamos, nos estudos analisados, que muitos partiram de uma inquietação do pesquisador.

\section{O conceito de colaboração na pesquisa}

Para dialogar sobre o conceito de colaboração, recorremos ao significado de Zona de Desenvolvimento Iminente (ZDI) de Vigotski (2001). Transportamos essa terminologia da Tese de Prestes (2010), elaborado com base em Vigotski (2000, 2001). Para a autora a ZDI é um dos conceitos vigotskianos mais utilizados e, ao mesmo tempo, mais vulgarizados por conta das traduções que tornou a interpretação desse conceito como possibilidade de 
desenvolvimento, Zona de Desenvolvimento Proximal (ZDP) (VYGOTSKY, 200o), ora como Zona de Desenvolvimento Imediato (VIGOTSKI, 2001).

Na interpretação da autora, o termo Zona de Desenvolvimento Proximal ou Zona de Desenvolvimento Imediato não deixa claro que a educação como atividade que esse desenvolvimento ocorra. Para ela, quando Vigotski (2001) refere-se ao papel da instrução (educação), ele não afirma que esse processo garante desenvolvimento. Compreendemos que, para esse pesquisador, a educação, quando realizada por meio de ação colaborativa entre pares, cria caminho para o desenvolvimento, mas não garante que essa instrução gere desenvolvimento.

Diante disso, consideramos que, como Vigotski (2001) defende que a educação cria a possibilidades de desenvolvimento, chamar a zona possibilidade de Zona de Desenvolvimento Iminente seja mais adequado. Entendemos que, na perspectiva de Vigotski (2001), a ZDI é as possibilidades que podem ser criadas e/ou organizadas para promover produção conjunta.

Um exemplo seria uma proposta de formação continuada, em que ocorra a produção conjunta, novos entendimentos sobre práticas e teorias, momentos de conflitos, que possam trazer questões e situações em que participantes e pesquisadores envolvam-se em questionamentos de situações reais que levam a uma formação crítica, criativa e empoderada que propicie práticas ideais.

Ao referir-se a ZDI, Magalhães (2009b) corrobora ao afirmar que uma determinada atividade formativa tem valor transformador se propiciar condições de desenvolvimento. Nesse sentido, o professor formador medeia a produção partilhada, considerando que o que se aprende, hoje, em colaboração, poderá fazer, amanhã, sozinho, e é essa condição que possibilita o desenvolvimento. Nos estudos Magalhães (2009b), a colaboração é compreendida como ferramenta-e-resultado da formação, conforme proposto por Vygotsky (2000). Com isso, compreendemos que colaborar requer criar condições de desenvolvimento com o outro, envolvendo-o em questionamentos em um processo reflexivo crítico, que se orienta pela relação teoria e prática.

Recorremos também a outros autores que discutem o conceito de colaboração, como Magalhães (2009a), que afirma ser uma categoria e que ela dá condições igual de negociação e responsabilidades, em um contexto que todos tenham voz e vez, em todos os momentos da pesquisa. Segundo Oliveira e Magalhães (2011), a colaboração é marcada pelo trabalho conjunto, apoio mútuo, objetivos comuns e ações não hierárquicas, em que os participantes tenham voz para expressar as suas experiências e opiniões.

Esses autores ressaltam que mesmo que haja participações diferenciadas, elas são realizadas coletivamente e que, para isso ocorrer, é preciso um ambiente em que os ISSN 2526-2882

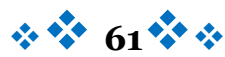


participantes vivenciem situações problemas sociais, vividos no contexto escolar, e que o foco seja as necessidades daquele contexto.

Essa colaboração efetiva-se com a interação entre pares, de acordo com o nível de desenvolvimento de cada participante, em que um par mais experiente dá ao outro com menos experiência, realizações nas atividades desenvolvidas, levando-os a avançar no seu nível de desenvolvimento, segundo Ibiapina (2008b). O avanço no nível de desenvolvimento pode ser o que eles conseguem realizar com os demais, como também o que ele consegue fazer independente, Vigostski (2001).

Para Ibiapina (2008b) e Desgagné (1997), colaborar não significa participação de todos com a mesma intensidade em todas as tarefas, mas contribuições específicas para um projeto comum. Os autores esclarecem que os participantes colaboram como coprodutores da investigação, tendo a possibilidade de compreender a prática docente.

É nesse ambiente de colaboração que ocorrem atitudes reflexivas sobre as práticas, afirmam Oliveira e Magalhães (2011) e é por meio delas e na relação com as práticas dos outros participantes que os professores podem encontrar manieras de mudá-las. Esse foco nas práticas é apontado por eles como a questão central para que ocorram transformações.

A colaboração que assumimos, nesta pesquisa, é compreendida por Oliveira e Magalhães (2011) como uma categoria, primeiro, por entenderem o conceito como "consciência da práxis pautada em um agir profissional dialógico, criativo, ético e competente quanto à concepção do objeto em foco” (p. 67), segundo, porque ela deve ser crítica e, para isso, "o professor necessita entender que o repensar as suas ações consiste em um exercício de aprofundamento e criatividade a fim de promover uma transformação e iniciar novas totalidades" (p. 68).

Essa colaboração crítica é entendida na prática como o desenvolvimento de trabalhos criativos, projetos coproduzidos que possam ser singulares e plurais, que expressam "multiplicidades de sentidos e significados cristalizados colocados, explicitados e questionados em vozes diversas, divergentes e contraditórias, mas possibilitadoras de significados compartilhados em um contexto que se organiza pela confiança e consideração ás colocações de outros, pelo foco na aprendizagem” (MAGALHÃES: OLIVEIRA, 2011 p. 71).

Nesse sentido, para analisar a colaboração, Magalhães e Oliveira (2011) pressupõem uma análise da organização das participações de todos em relação às próprias e as de outros. É uma análise, segundo eles, dos tipos de perguntas, dos silêncios, da retomada da fala, do interesse e das considerações pelo que está em discussão e dos questionamentos com foco nas contradições. 
Com base nos estudos desses autores, identificamos algumas características, as quais adotaremos neste trabalho e recorreremos na análise dos dados. Essas características estão presentes nas ações de colaboração, como mostra a Figura 1.

Figura 1 - características da colaboração

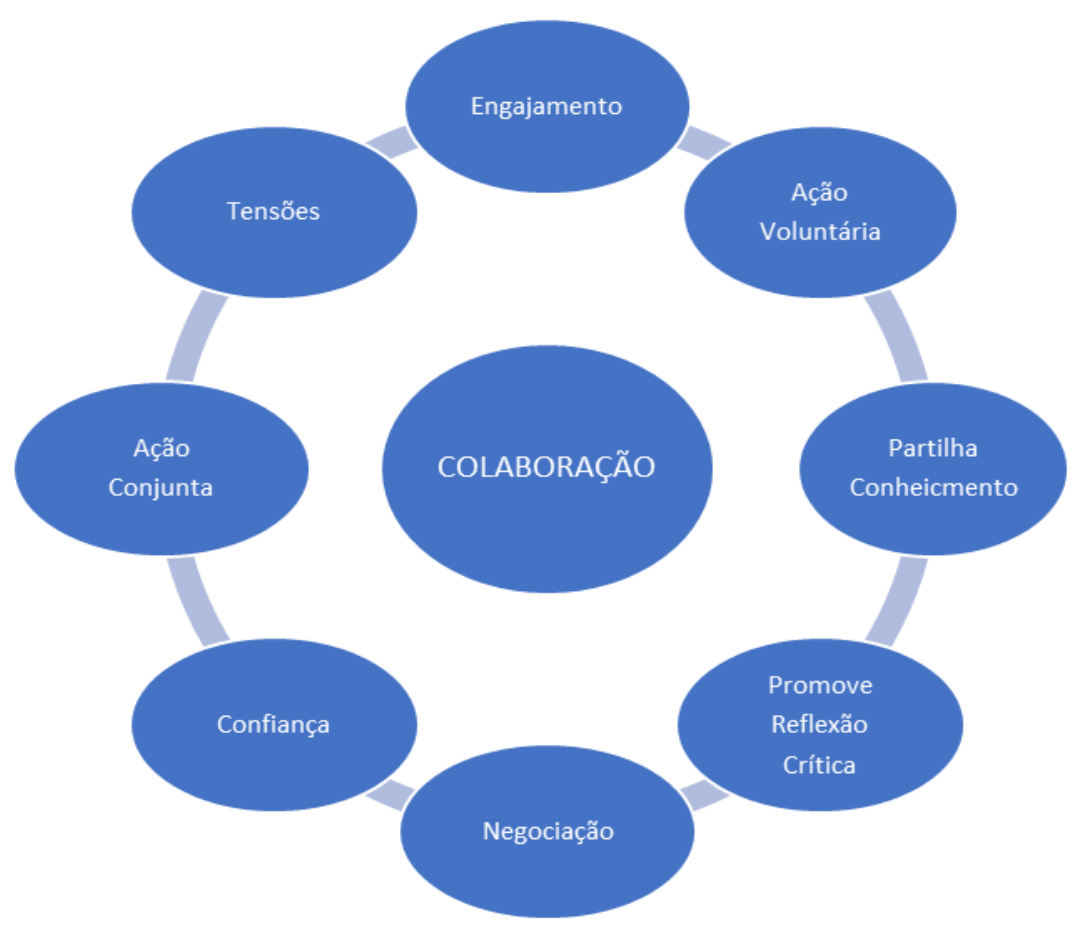

Fonte: Produzido pela pesquisadora com base em Ibiapina (2008a, 2008b), Magalhães e Oliveira (2011), Vygostsky (2001) e outros.

Compreendemos que colaborar envolve tensões e contradições, assim, procuramos, durante o desenvolvimento da proposta de formação continuada, criar um ambiente que possibilitasse aos professores conscientizarem-se acerca das consequências de suas ações, trazendo à tona o confronto e buscando a reconstrução de suas práticas.

\section{Aspectos Metodológicos}

A opção por desenvolver este trabalho na perspectiva da colaboração justifica-se, pois, a Pesquisa Colaborativa é uma modalidade de investigação voltada para o desenvolvimento e a emancipação profissional de professores, podendo transformar práticas tradicionais em emancipatórias, assim como promover reflexão crítica colaborativa no processo de investigação (FERREIRA, 2007). Para Ibiapina (2008a, p. 26), “[...] o diferencial dessa investigação está em dar conta da realidade microssocial sem perder de vista o aspecto histórico e político do macro contexto social”. Com isso, compreendemos que essa 
modalidade de pesquisa possibilita aos professores participantes da proposta de formação a compreensão sobre a relação entre o que eles vivenciam na sala de aula, sendo para eles o ideal, e o que realmente lhes é imposto. Assim, a pesquisa colaborativa é uma metodologia de pesquisa desenvolvida por Ibiapina, sendo uma abordagem da pesquisa-ação, pois, segundo ela, "alia investigação e formação em processos de compreensão, interpretação e transformação de realidades sociais” (IBIAPINA, 2008a p. 11). Por isso, essa perspectiva é considerada, por Ibiapina, como uma via de mão dupla.

Essa abordagem está fundamentada no referencial teórico e metodológico da Teoria Sócio-Histórico-Cultural e trata de uma modalidade de pesquisa voltada para o desenvolvimento e o empoderamento profissional de professores e pesquisadores simultaneamente. Nesse sentido, Ibiapina (2008a, p. 34) afirma que:

Na pesquisa colaborativa, o pesquisador colabora com os professores quando contribuí para o desenvolvimento profissional, quando planeja sessões de formação, ajudando a enfrentar a complexidade das situações educativas às quais eles se confrontam cotidianamente, e quando, graças ao discurso desses profissionais, reinterpreta a teoria com base na prática (IBIAPINA, 2008a, p. 34)

As consequências dessa investigação colocam o pesquisador como co-construtor, juntamente com os docentes, tornando essa atividade simultaneamente pesquisa e formação. Aliar-se aos professores e co-construir um objeto de conhecimento é colocá-los em processo de aperfeiçoamento, afirma Desgagné (2007).

A investigação que a pesquisa colaborativa refere-se deve partir sempre da prática social e, como afirma Kemmis (1987), atender três condições, incluindo a necessidade de ser colaborativa; possuir ciclos reflexivos críticos e envolver a co-produção de saberes. Essas três condições são propostas por Kemmis (1987) e adotadas por Ibiapina (2008).

O conceito de colaboração é discutido por Desgagné (2007), considerando-o a partir de uma ideia que provém do abismo existente entre universidade e escola. Mas, onde estaria o problema? A discussão é longa e a sua intenção é motivar pesquisadores universitários e docentes e tentar entender no que se fundamenta essa colaboração.

Um dos fatores principais é considerar o contexto real em que a investigação ocorre, os recursos existentes e os seus componentes estão inseridos, pois o pesquisador deve considerar o ponto de vista e as reflexões que o professor faz sobre a sua própria prática e procurar o seu objeto de investigação no interior desse contexto, de modo que juntamente com os professores, compreender em que se apoia o seu agir.

Nesse contexto, o pesquisador torna-se aliado dos docentes, co-construindo um objeto de conhecimento e envolvendo-os num processo de aperfeiçoamento, tornando um ambiente de pesquisa e formação. Nessa dupla perspectiva, o objeto, a metodologia e o 
quadro conceitual são tarefas de responsabilidades do pesquisador, dos docentes é solicitada a participação no processo de reflexão sobre a sua prática, levando-os a explorar situações novas ou já vivenciadas.

É por meio desse processo de reflexão que está envolto em uma situação prática escolhida pelos docentes que o pesquisador investiga o seu objeto e ocorre a co-construção (DESGAGNÉ, 2007). Embora a pesquisa colaborativa apresentada até este momento possua duas perspectivas, pesquisa e formação, e tem em comum a melhoria da prática por meio da produção de conhecimento, conforme reforçado pelo autor, o conceito de colaboração apoiase na compreensão e interesse dado pelos pesquisadores, que avançam nos conhecimentos, e pelos professores, quando buscam a melhoria da prática no projeto de investigação.

Nessa abordagem, o pesquisador exerce a função de formador quando atende as necessidades dos professores, como a dificuldade de aprendizagem dos alunos, ou quando apoia os professores iniciantes. Nesse caso, o objeto de investigação pode surgir no decorrer do processo de formação ou de forma planejada, o pesquisador pode desenvolver um projeto que unirá a investigação de seu objeto e um processo de desenvolvimento profissional. $\mathrm{O}$ desafio é o mesmo para ambos os papéis, pois terá que unir pesquisa e formação por meio da co-construção e da reflexão com os professores (DESGAGNÉ, 2007).

Outra ambiguidade que o autor aponta existir na investigação colaborativa está na participação que se espera dos docentes. Por se tratar de pesquisa colaborativa, ele entende que todos deverão participar de todas as etapas formais da pesquisa. Os docentes não são excluídos das etapas formais da pesquisa, como definição de objeto, coleta de dados, análise e publicação, mas a forma que estamos compreendendo esse tipo de investigação não exige que os docentes participem como co-pesquisadores.

Entretanto, eles podem ter como objetivo a formação para pesquisa se considerarem isso indispensável para o seu desenvolvimento profissional. A verdadeira contribuição docente está na sua participação como co-construtores do projeto de investigação. Para Desgagné (2007), colaborar é cada participante oferecer a sua contribuição específica, beneficiando todo o conjunto.

Com isso, entendemos que essa modalidade de pesquisa constitui-se em atividade de coprodução de conhecimentos, formação, reflexão e desenvolvimento profissional, sendo esses elementos fundamentais desta pesquisa, que possui, como componentes básicos, a mediação e a colaboração.

Dessa forma, realizamos esta investigação interativamente por pesquisadores e professores, tendo como objetivo a melhoria da prática e a transformação da realidade dos participantes por meio da mediação e da colaboração na formação continuada para professores de Matemática. 
No desenvolvimento desta pesquisa colaborativa, os participantes valorizam, em várias situações, o pensamento de seus pares, considerando situações semelhantes e divergentes de pensar e agir do outro, como, por exemplo, em discussões envolvendo o planejamento de atividades e análise das aulas desenvolvidas durante as sessões colaborativas e reflexivas.

Nas sessões colaborativas, apreendemos que os professores analisavam conjuntamente as suas ações e compartilhavam momentos conflituosos vividos em suas práticas, o que contribuiu para que construíssem conhecimentos e levassem a compreensão das reais condições de seu contexto de trabalho e a articulação entre teoria e prática.

Com isso, ampliamos as possibilidades de os professores conhecerem formalmente significados internalizados, de poder confrontá-los e reconstruí-los. A proposta de formação continuada levou-os a compartilhar significados e, por meio do processo reflexivo, tomar consciência de ideias internalizadas, como também redefinir e reorientar os conceitos e as práticas que vivem em outros formatos de cursos de formação continuada.

Diante disso, apresentamos, na Figura 2, algumas características da pesquisa colaborativa que se fizeram presentes no desenvolvimento deste trabalho:

Figura 2 - características da pesquisa colaborativa

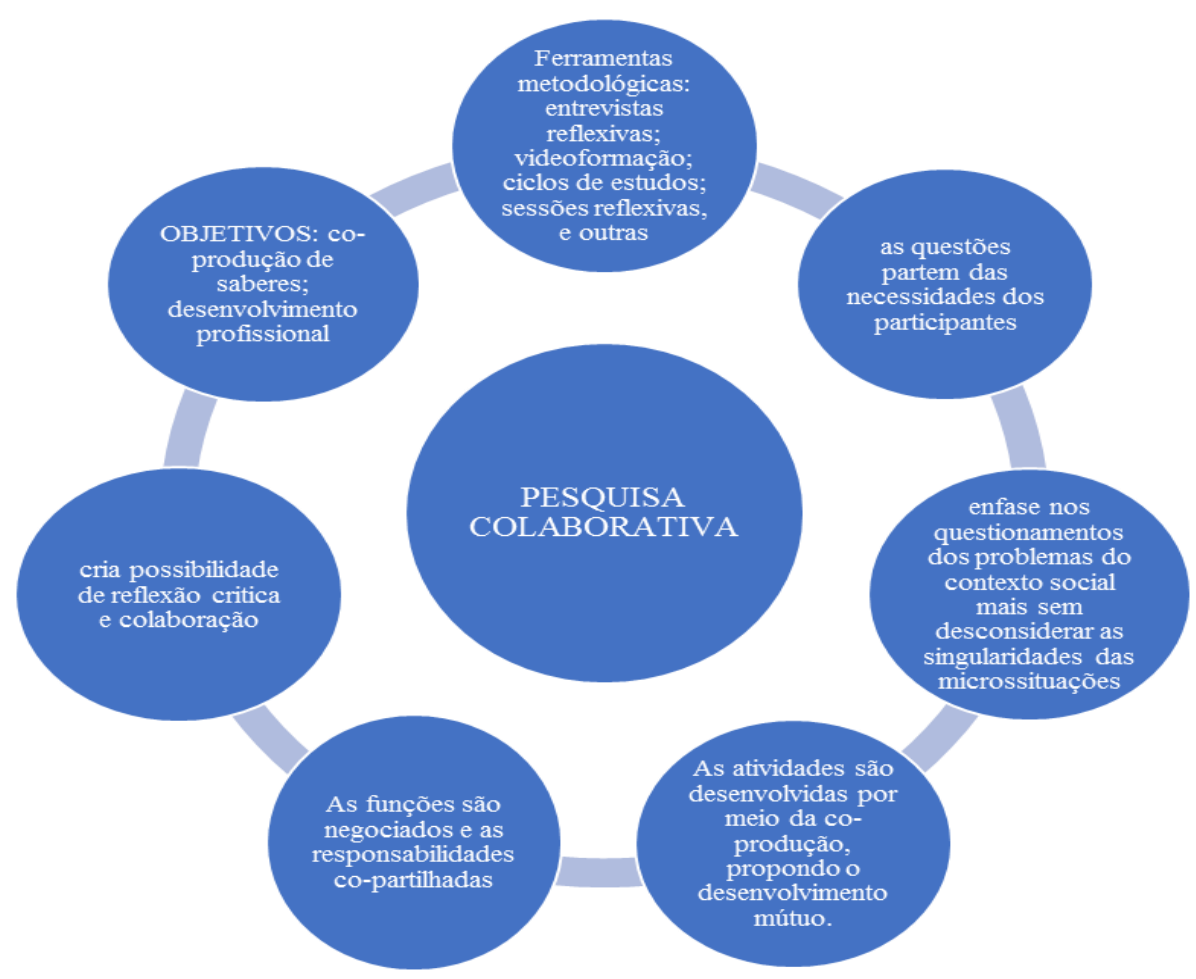

Fonte: Ibiapina (2008) 
Com base nas ideias de Magalhães (2009a), entendemos que fizemos, desta pesquisa colaborativa, instrumento capaz de proporcionar sessões produtivas, em que o grupo pode resolver conflitos, partilhar conhecimentos e experiências e, assim, dar significado em suas ações, pois, a autora pondera que colaborar envolve situações tensas que geram conflitos, que são fundamentais para a reflexão crítica e essas situações propiciam transformações relevantes nos modos de pensar e agir. Sobre a pesquisa colaborativa, Magalhães (2009a, p. 236) afirma que:

A pesquisa colaborativa deve ser entendida como um espaço para o autoconhecimento, para questionamentos de conceitos científicos rotinizados e alienados dos interesses a que servem, de forma a permitir a todos a atribuição de novos sentidos e produção de significados compartilhados, isto é, um contexto de empoderamento. (MAGALHÃES, 2009a, p. 236)

Assim posto, pesquisar colaborativamente envolve parceria, engajamento, trabalho conjunto, dentre outros. Um processo de colaboração implica passar por todas as fases ao longo de todo processo investigativo, como afirma Ibiapina (2008a).

Para desenvolver a proposta de formação continuada, contexto desta pesquisa, o grupo discutiu e negociou conjuntamente, levantaram-se as necessidades dos participantes que destacaram pontos relevantes pertencentes às suas práticas. O grupo conheceu sobre o recorte teórico-metodológico, por meio de estudos de textos, e planejamos o trabalho de campo, como também definimos os cronogramas para a realização das sessões, discutimos, além disso, as contribuições de cada participante do grupo, como mostra o diálogo nas sessões que iniciaram o ano de 2014, em que o grupo começou as ações nas escolas.

Durante a realização da formação foi planejado conjuntamente, desenvolvido e depois discutido de forma colaborativa, vários planos de aula atendendo as necessidades dos participantes, sempre tomando como base os dizeres de Ibiapina (2008a) ao afirmar que:

Na pesquisa colaborativa, o pesquisador colabora com os professores quando contribuí para o desenvolvimento profissional, quando planeja sessões de formação, ajudando a enfrentar a complexidade das situações educativas às quais eles se confrontam cotidianamente, e quando, graças ao discurso desses profissionais, reinterpreta a teoria com base na prática. (IBIAPINA, 2008a, p. 34)

Dessa forma, colaboramos com os participantes quando proporcionamos, por meio de algumas ferramentas metodológicas, o desenvolvimento profissional, ou melhor, quando planejamos aulas, desenvolvemos e refletimos sobre essas ações, e realizamos sessões colaborativas e reflexivas, além de videogravações. 
As discussões realizadas nas sessões colaborativas mostraram-se como grandes oportunidades para que os professores visualizassem as suas atuações, realizando uma reflexão crítica inter e intrapsicológica e confrontando teoria e prática.

Foi por meio da reflexão crítica que os professores superaram antigas visões de suas práticas, tendo uma visão retrospectiva de suas ações, em que questionaram as suas teorias e experiências. Com isso, buscamos intervenções por meio desta pesquisa, fazendo-o embasadas em questionamentos, levando os participantes a refletirem criticamente as suas ações, com o intuito de transformá-las. Cabe ressaltar que a nossa intenção foi realizar esta pesquisa com os professores e não sobre professores, fazendo-os partícipes do processo investigativo.

Cabe ressaltar que a formação continuada que gerou os dados para esta investigação estava atrelado ao projeto intitulado "Trabalho colaborativo com professores que ensinam Matemática na Educação Básica em escolas públicas das regiões Nordeste e Centro-Oeste”, vinculado ao Programa Observatório da Educação (OBEDUC), criado pelo Decreto Presidencial $n^{0} 5.803$, de oito de junho de 2006, resultado da parceria entre a Coordenação de Aperfeiçoamento de Pessoal de Nível Superior - CAPES, o Instituto Nacional de Estudos e Pesquisas Educacionais Anísio Teixeira - INEP e a Secretaria de Educação Continuada, Alfabetização, Diversidade e Inclusão - SECADI.

Esse programa foi criado com o intuito de fomentar a produção acadêmica e a formação de profissionais com Pós-Graduação Stricto Sensu em Educação e apresentou-se como uma política pública de formação e desenvolvimento profissional de professores. Ele buscou o fortalecimento e o diálogo entre as Universidades, as políticas nacionais de Educação, visava também à articulação entre Pós-Graduação, licenciaturas e escolas de Educação Básica, além de estimular a produção acadêmica em nível de mestrado e doutorado.

O projeto no qual realizamos nossa investigação foi realizado em rede e teve a Universidade Federal de Mato Grosso do Sul (UFMS) como instituição sede, contando com a participação da Universidade Estadual da Paraíba (UEPB) e a Universidade Federal de Alagoas (UFAL). Esse projeto teve a duração de três anos, iniciando no primeiro semestre de 2013 e finalizando no primeiro semestre de 2016, tendo sido composto por quatro mestrandos em Educação Matemática, quatro Licenciandos em Matemática da UFMS, oito professores da Educação Básica da rede pública de Campo Grande e uma coordenadora Institucional. Os professores foram identificados como P1, P2, ..., os mestrando como M1, $\mathrm{M} 2, \ldots$, os licenciandos como L1, L2, ...., e a pesquisadora como PS.

Com base nos dados obtidos a partir dos estudos de Vigotski (2000a), Ibiapina (2008) e Magalhães (2007), este trabalho optou pela Pesquisa Colaborativa que selecionou a ISSN 2526-2882 
Colaboração como alicerce da investigação. Para desenvolver a proposta de formação continuada, dispusemos de alguns procedimentos metodológicos que produziram os dados do nosso objeto de estudo, favorecendo o processo de colaboração no grupo.

Selecionamos instrumentos metodológicos que possibilitassem os participantes compreenderem que teoria e prática (real e ideal) são elementos que não se podem dissociar, por isso, devemos sempre discutir e analisá-los, almejando uma prática transformadora. Diante dessa compreensão, utilizamos sessões colaborativas na produção dos dados. Identificamos, como as sessões colaborativos, os encontros que realizamos, as negociações, esclarecimentos sobre a proposta de formação continuada, leituras reflexivas, compartilhamentos de experiências entre os participantes e elaboração de plano de aulas.

Neste trabalho, pesquisadores e professores reuniram-se em sessões colaborativas para concretizar esta investigação. Os dados analisados nesta pesquisa foram produzidos no total de 32 sessões colaborativas, essas sessões possibilitaram momentos de negociações, interação e colaborações. Por meio dessas sessões, os professores conheceram a Pesquisa Colaborativa que lhes permitiu compreenderem a importância de fazerem parte do trabalho desenvolvido em colaboração.

Para que, nessas sessões, todos soubessem quais seriam as suas atribuições no decorrer do processo de formação, utilizamos o que sugere Ibiapina (2008a), como sendo atribuições que podem ser negociadas no processo de investigação colaborativa, conforme Quadro 1 (um).

Quadro 1 - sugestões de atribuições dos participantes

\begin{tabular}{|c|c|}
\hline PESQUISADORES & PARTICIPANTES \\
\hline $\begin{array}{l}\text { Organizar as sessões colaborativas e reflexivas, } \\
\text { selecionar os textos para estudo e estimular a } \\
\text { participação de todos no grupo; } \\
\text { Levantar conceitos nas necessidades formativas; } \\
\text { Levar para discussão, no grupo, o resultado do } \\
\text { levantamento, para definição dos conceitos a serem } \\
\text { trabalhados; } \\
\text { Fazer o diagnóstico dos conhecimentos prévios } \\
\text { sobre os conceitos definidos; } \\
\text { Aplicar os instrumentos de coleta de informação e } \\
\text { transcrevê-las; } \\
\text { Organizar os textos para o estudo dos conceitos } \\
\text { Mediar as sessões reflexivas; } \\
\text { Divulgar os resultados do estudo individualmente } \\
\text { ou em parceria. }\end{array}$ & $\begin{array}{l}\text { Aprovar os conceitos selecionados no } \\
\text { levantamento das necessidades formativas; } \\
\text { Definir os conceitos a serem trabalhados; } \\
\text { Responder ao diagnóstico dos conhecimentos } \\
\text { prévios; } \\
\text { Participar ativamente de todas as atividades } \\
\text { propostas pela pesquisa; } \\
\text { Apresentar-se como voluntário para montagem } \\
\text { do videoteipe; } \\
\text { O voluntário deve ficar responsável por obter o } \\
\text { consentimento da turma que será fotografada e } \\
\text { filmada; } \\
\text { Ler com antecedência os textos; } \\
\text { Colaborar com os pares nas ações reflexivas; } \\
\text { Divulgar os resultados do estudo em parceria } \\
\text { com algum integrante. }\end{array}$ \\
\hline
\end{tabular}
Fonte: Ibiapina (2008, adaptado pela pesquisadora).

Este projeto teve início em 2013 e os seus primeiros meses foram envolvidos com o processo de seleção dos participantes, a instituição financiadora previa para esse núcleo 
bolsas para mestrandos, professores da Educação Básica e licenciandos. Foram realizadas nove sessões no segundo semestre desse ano, todas tiveram a duração de até 120 minutos e ocorreram em uma sala da unidade VII da UFMS, além de uma escola Estadual de ensino de Campo Grande. As sessões foram gravadas para posteriores transcrições, visando às análises de pesquisas futuras.

Consideramos as sessões realizadas em 2013 como colaborativas, no sentido de serem voltadas para estudo de textos, referências teóricas com leituras que discutiram a ideia de colaboração, prática docente, reflexão e outros conceitos que permeariam os trabalhos do grupo, para que todos compreendessem algumas abordagens sobre a profissão docente, a questão do profissional docente, sobre as práticas colaborativas, os trabalhos colaborativos e o grupo colaborativo.

No ano de 2014 e 2015, foram realizadas 23 sessões colaborativas. Durante esses dois anos, o grupo subdividiu-se em subgrupos para que pudesse atender as necessidades dos professores, visto que o objetivo do projeto, ao qual a proposta de formação estava vinculada, era propiciar, por meio de práticas colaborativas, a reflexão dos professores sobre o trabalho didático/pedagógico e desencadear ações educativas voltadas para a sala de aula.

Durante esses anos, os participantes elaboraram e desenvolveram planos de aulas que foram produzidos a partir das necessidades dos professores que estavam atuando na educação básica. Além das sessões semanais, os subgrupos se reuniam mensalmente para um encontro geral em que eram discutidos e apresentados os trabalhos realizados nos subgrupos. Para isso, construímos o Quadro 2 (dois), exposto a seguir, que apresenta um resumo dessas sessões colaborativas.

Quadro 2 - temas, assunto ou textos explorados durante o processo de investigação

\begin{tabular}{|c|c|c|}
\hline SESSÕES & TEMA/ASSUNTO OU TEXTO & OBJETIVOS DAS SESSÕES \\
\hline $1^{\text {a }}$ Sessão 17/08/13 & $\begin{array}{l}\text { Apresentação do projeto Filme sobre } \\
\text { colaboração }\end{array}$ & $\begin{array}{l}\text { Mostrar a importância do trabalho em } \\
\text { equipe }\end{array}$ \\
\hline $2^{\text {a }}$ Sessão 09/09/13 & Música "tocando em frente" & Propiciar a interação do grupo. \\
\hline $3^{\text {a }}$ Sessão 16/09/13 & $\begin{array}{l}\text { Texto: "A formação do professor } \\
\text { investigador na escola } \\
\text { possibilidades as } \\
\text { colaborativa: um retrato sem retoques" } \\
\text { (GRÍGOLI et al., 2007). }\end{array}$ & $\begin{array}{l}\text { Discutir sobre o conceito de prática e } \\
\text { possíveis mudanças a partir do } \\
\text { trabalho em grupo. }\end{array}$ \\
\hline $4^{\mathrm{a}}$ Sessão 07/10/13 & $\begin{array}{l}\text { Para uma formação de professores } \\
\text { construída dentro da profissão - } \\
\text { (NÓVOA, 2009) }\end{array}$ & A formação de um bom professor \\
\hline $5^{\text {a }}$ Sessão 08/10/13 & $\begin{array}{l}\text { Sessão realizada em uma escola } \\
\text { pública de Campo Grande }\end{array}$ & $\begin{array}{l}\text { Levantar junto aos professores os } \\
\text { problemas no ensino e aprendizagem } \\
\text { da Matemática que enfrentavam em } \\
\text { sala de aula }\end{array}$ \\
\hline $6^{\text {a }}$ Sessão 04/11/13 & $\begin{array}{l}\text { Investigar nossa própria prática: uma } \\
\text { estratégia de formação e de construção } \\
\text { do conhecimento profissional. } \\
\text { (PONTE, 2008) }\end{array}$ & O professor pesquisador \\
\hline
\end{tabular}

ISSN 2526-2882 


\begin{tabular}{|c|c|c|}
\hline $7^{\mathrm{a}}$ Sessão 11/11/13 & $\begin{array}{llr}\text { Pesquisa } & \text { Colaborativa: } & \text { Investigação, } \\
\text { formação e e } & \text { produção } & \text { de } \\
\text { conhecimentos, } & \text { Primeira } & \text { Parte. } \\
\text { (IBIAPINA, 2008) } & & \end{array}$ & $\begin{array}{l}\text { Discutir e compreender o conceito de } \\
\text { colaboração na formação continuada. }\end{array}$ \\
\hline $8^{\text {a }}$ Sessão 18/11/13 & $\begin{array}{llr}\text { Pesquisa } & \text { Colaborativa: } & \text { Investigação, } \\
\text { formação e } & \text { produção } & \text { de } \\
\text { conhecimentos, } & \text { Primeira } & \text { Parte. } \\
\text { (IBIAPINA, 2008) } & & \end{array}$ & $\begin{array}{lll}\text { Levantar } & \text { questões } & \text { sobre } \\
\text { transformação, emancipação } & \text { e a } \\
\text { diferença entre colaborar e cooperar. }\end{array}$ \\
\hline $9^{\text {a }}$ Sessão 09/12/13 & $\begin{array}{l}\text { Discussão da agenda de } 2014 \text { e das } \\
\text { atividades de } 2013\end{array}$ & $\begin{array}{l}\text { Produzir uma escrita sobre as } \\
\text { principais concepções a respeito das } \\
\text { atividades realizadas no segundo } \\
\text { semestre de 2013. }\end{array}$ \\
\hline $\begin{array}{ll}10^{\mathrm{a}} & \text { Sessão } \\
27 / 02 / 14 & \end{array}$ & $\begin{array}{l}\text { As necessidades dos professores } \\
\text { atuantes na Educação Básica }\end{array}$ & $\begin{array}{l}\text { Levantar as necessidades do grupo. } \\
\text { Propor escrita de relatos reflexivos e } \\
\text { autobiografias. }\end{array}$ \\
\hline $\begin{array}{ll}11^{\mathrm{a}} & \text { Sessão } \\
06 / 03 / 14 & \end{array}$ & Reunião geral do OBEDUC & $\begin{array}{l}\text { Apresentar propostas de atividades } \\
\text { frente às necessidades levantadas pelos } \\
\text { participantes }\end{array}$ \\
\hline $\begin{array}{ll}12^{\mathrm{a}} & \text { Sessão } \\
27 / 03 / 14 & \end{array}$ & $\begin{array}{l}\text { Livro: Histórias de aulas de } \\
\text { Matemática: compartilhando saberes } \\
\text { profissionais (Fiorentini e Jiménez, } \\
\text { s/d) }\end{array}$ & $\begin{array}{l}\text { Discutir os artigos dos livros sobre } \\
\text { trabalhos realizados em grupos. } \\
\text { Escolher o conteúdo a ser trabalhado }\end{array}$ \\
\hline $\begin{array}{ll}13^{\mathrm{a}} & \text { Sessão } \\
14 / 04 / 14 & \end{array}$ & Planejamento & $\begin{array}{l}\text { Planejar uma aula sobre noções de } \\
\text { frações relacionando capacidade }\end{array}$ \\
\hline $\begin{array}{l}14^{\mathrm{a}} \\
24 / 04 / 14\end{array}$ & Reunião geral & Apresentar o planejamento \\
\hline $\begin{array}{l}15^{\mathrm{a}} \\
28 / 04 / 14\end{array}$ & Planejamento & $\begin{array}{l}\text { Discutir o planejamento de aula sobre } \\
\text { Fraçôes utilizando o Tangran }\end{array}$ \\
\hline $\begin{array}{l}16^{\mathrm{a}} \\
05 / 06 / 14\end{array}$ & Reunião geral & $\begin{array}{l}\text { Participar da apresentação } \\
\text { trabalhos dos outros subgrupos }\end{array}$ \\
\hline $\begin{array}{ll}17^{\mathrm{a}} & \text { Sessão } \\
23 / 03 / 15 & \end{array}$ & Reunião geral & Organização das ações para 2015 \\
\hline $\begin{array}{l}18^{\mathrm{a}} \\
09 / 04 / 15\end{array}$ & Necessidades do subgrupo & $\begin{array}{l}\text { Levantar as necessidades do subgrupo } \\
\text { para ano de } 2015\end{array}$ \\
\hline $\begin{array}{l}19^{\mathrm{a}} \\
16 / 04 / 15\end{array}$ & Planejamento & $\begin{array}{l}\text { Discutir quais ações seriam realizadas } \\
\text { a partir das necessidades levantadas } \\
\text { sobre o conteúdo de geometria }\end{array}$ \\
\hline $\begin{array}{l}20^{\mathrm{a}} \\
23 / 04 / 15\end{array}$ & Planejamento & $\begin{array}{l}\text { Discutir possibilidades de elaborar } \\
\text { algum material para trabalhar com o } \\
\text { ensino de geometria }\end{array}$ \\
\hline $\begin{array}{l}21^{\mathrm{a}} \\
23 / 04 / 15\end{array}$ & Reunião geral & $\begin{array}{l}\text { Estudar a metodologia da pesquisa } \\
\text { colaborativa }\end{array}$ \\
\hline $22^{\mathrm{a}}$ & Planejamento & $\begin{array}{l}\text { Elaborar um planejamento sobre } \\
\text { geometria, para o oitavo do Ensino } \\
\text { Fundamental }\end{array}$ \\
\hline $\begin{array}{l}23^{\mathrm{a}} \\
14 / 05 / 15\end{array}$ & Planejamento & $\begin{array}{lll}\begin{array}{l}\text { Elaborar as } \\
\text { planejamento }\end{array} & \text { atividades do } \\
\end{array}$ \\
\hline $\begin{array}{l}24^{\mathrm{a}} \\
27 / 05 / 15\end{array}$ & Reunião geral & $\begin{array}{l}\text { Estudar a metodologia da pesquisa } \\
\text { colaborativa }\end{array}$ \\
\hline $\begin{array}{l}25^{\mathrm{a}} \\
17 / 06 / 15\end{array}$ & Planejamento & $\begin{array}{l}\text { Discutir as atividades elaboradas sobre } \\
\text { geometria }\end{array}$ \\
\hline $27 / 06 / 15$ & Planejamento & $\begin{array}{lll}\text { Discutir os próximos conteúdos } & \text { a } \\
\text { serem trabalhos atendendo } & \text { o } \\
\text { referencial curricular } & & \end{array}$ \\
\hline $\begin{array}{l}27^{\mathrm{a}} \\
11 / 06 / 15\end{array}$ & Reunião geral & $\begin{array}{l}\text { Apresentar e discutir a atividade sobre } \\
\text { volume, com o uso de figuras e } \\
\text { recipientes de vidro. }\end{array}$ \\
\hline
\end{tabular}




\begin{tabular}{|ll|l|l|}
\hline $\begin{array}{l}28^{\mathrm{a}} \\
22 / 06 / 15\end{array}$ & Sessão & Reunião geral & $\begin{array}{l}\text { Apresentar as atividades desenvolvidas } \\
\text { em sala de aula sobre geometria }\end{array}$ \\
\hline $\begin{array}{l}29^{\mathrm{a}} \\
20 / 08 / 15\end{array}$ & Sessão & Planejamento & $\begin{array}{l}\text { Elaborar atividades relacionadas ao } \\
\text { volume de cubo e paralelepípedo }\end{array}$ \\
\hline $\begin{array}{l}30^{\mathrm{a}} \\
17 / 09 / 15\end{array}$ & Sessão & Planejamento & $\begin{array}{l}\text { Elaborar atividades sobre planificação } \\
\text { de figuras }\end{array}$ \\
\hline $\begin{array}{l}31^{\mathrm{a}} \\
08 / 10 / 15\end{array}$ & Sessão & Planejamento & $\begin{array}{l}\text { Discutir as atividades do planejamento } \\
\text { sobre planificação de figuras }\end{array}$ \\
\hline $\begin{array}{ll}32^{\mathrm{a}} \\
22 / 10 / 15\end{array}$ & Sessão & Planejamento & $\begin{array}{l}\text { Discutir as atividades do planejamento } \\
\text { sobre planificação de figuras }\end{array}$ \\
\hline
\end{tabular}

Fonte: Elaborado pelas autoras

Cabe destacar que, durante as sessões consideradas colaborativas, tanto estudo de textos, planejamentos de atividades, quanto para as discussões relacionadas às situações de sala de aula, música e filme que assistimos, constituíram-se, nesta investigação, instrumentos que fizeram emergir o pensamento crítico reflexivo dos participantes, propiciando embasamento teórico para as práticas de aula.

Por fim, consideramos que essas sessões colaborativas foram momentos essenciais para a construção da colaboração no grupo e para identificarmos e compreendermos as interações entre os participantes. As discussões realizadas e os momentos para estudos compartilhados possibilitaram, por meio de uma postura crítica, momentos de crescimento pessoal e profissional para todos os participantes do grupo.

\section{Movimentos de Colaboração}

Buscamos, nas análises, compreender os movimentos de colaboração ocorridos durante o processo formativo por meio da metodologia da pesquisa colaborativa. Nas sessões colaborativas, os momentos de estudos, discussão e planejamentos de aula, trouxeram discussão e situações que se configuraram em movimentos que podem ser considerados colaboração. Nesses movimentos, destacamos diferenças particulares que entendemos permear ações de dividir, ajudar e colaborar em um contexto educativo. Essas ações, no desenvolvimento da pesquisa, constituíram o eixo temático colaboração, construído com base nos discursos produzidos nas sessões.

Quadro 3 - eixo temático

\begin{tabular}{|l|l|l|}
\hline \multicolumn{1}{|c|}{ COLABORAÇÃO } \\
\hline \multirow{3}{*}{$\begin{array}{l}\text { Sessões colaborativas } \\
\text { e }\end{array}$} & \multicolumn{1}{|c|}{ Categoria Analítica } & \multicolumn{1}{|c|}{ Indicadores Interpretativos } \\
\cline { 2 - 3 } Entrevista coletiva & Interações & -Colaborar entre os participantes; \\
& Colaborativas & -Apoio mútuo; \\
& -Objetivo comum; \\
& -Ações não hierárquicas; \\
& - Falas que indicam colaboração nas \\
& ideias e no agir; \\
& - Pronomes utilizados: nós, o grupo, \\
& todos, juntos. \\
\hline
\end{tabular}

Fonte: Produzido pela autora badesado em Ibiapina (2008), Magalhães (2011) e Oliveira (2009). ISSN 2526-2882 
Com base nesse eixo, a categoria colaboração, além de constituir uma categoria de análise, é também uma maneira de compreender o nível de colaboração desenvolvido durante a realização do projeto. Apresentamos, a seguir, os relatos e os momentos durante as sessões que revelaram como o grupo foi se constituindo e de que forma a colaboração permeou esses momentos, os professores envolvidos no processo de formação compartilharam vivência e experiência com seus pares e puderam mostrar a realidade da sala aula aos colegas ainda em formação.

Percorremos as transcrições das sessões colaborativas buscando momentos que podemos identificar colaboração por meio das características e dos indicativos descritos no Quadro 3. A partir deles, conseguimos analisar se houve colaboração e de que forma a colaboração pode contribuir com os participantes desta investigação. A seguir, apresentamos trechos das sessões colaborativas realizadas em que compreendemos que pode ser considerada a existência de indícios de colaboração.

Ao retornar as sessões no ano de 2014, o grupo discutiu os conteúdos que seriam abordados e elaborou atividades a partir das necessidades da escola em que P1 atuava, nesse momento, iniciaram as ações nas escolas e, para isso, o grupo negociava as atribuições cada um. Na sessão 11, as licenciandas questionaram qual seria o seu papel na pesquisa:

G1: $\mathrm{E}$ as licenciandas entram em quê?

P2: Transcrição.

(risos)

Valentina: Boa pergunta. O papel das licenciandas é nos auxiliar em tudo. P3: Ah! Então, eu vou participar da transcrição também.

(SESSÃO 11, 03/2014)

Ibiapina (2008a) reforça que o trabalho colaborativo e a negociação de atribuições que viabilizam a colaboração entre os participes devem criar um clima democrático para enfrentá-lo e geri-lo coletivamente. No diálogo apresentado a seguir, os professores tentam negociar o que será trabalhado, há uma tentativa de negociação, mas ainda há indícios de hierarquia.

P1: Eu preciso saber, porque nós vamos definir a turma. E o conteúdo .... ? P2: Pode ser, por exemplo, um conteúdo que eu já trabalhei? Aí eu desenvolvo coisa diferente.

M1: [...] O nosso papel vai ser essa questão de ajudar vocês a produzir um material para nós aplicarmos lá. Esse é o nosso papel. [...] Nós vamos produzir o que nós vamos trabalhar, por exemplo, frações, aí nós vamos pesquisar.

(SESSÃO 12, 03/2014) 
$\mathrm{Na}$ busca por romper com a hierarquia, os participantes sempre retomam a fala e buscam corrigir os termos usados para que o trabalho possa atingir a colaboração. Nessa mesma sessão, M1 retoma a fala e reforça a importância das características da colaboração discutidas nas sessões anteriores.

M1: Porque para haver a colaboração tem que existir a parceria entre Professor Universitário, Professor da Educação Básica, Mestrandos, Doutorandos e entre os Licenciandos. Essas interações podem denominar de ciclo de colaboração, pois cada integrante do grupo tem que estar disposto a ouvir o próximo, buscar subsídios para ajudar na reflexão dos pares.

(SESSÃO 12, 03/2014)

A fala de M1 mostra indícios do entendimento do conceito de colaboração, como também mostra o objetivo comum do grupo, principalmente, no momento em que P1, ao relatar sobre o seu trabalho na escola em que o diretor apoia o seu envolvimento no projeto, descreve o trabalho para o seu Diretor da seguinte forma:

P1: No trabalho que desenvolvemos lá, todo mundo ouve todo mundo e cada um tem uma opinião. Essa troca de informação faz com que tenhamos uma visão mais para fora da sala de aula.

(SESSÃO 12, 03/2014)

E, nesse ambiente de trabalho, o grupo levantava as necessidades para iniciar as ações nas escolas. A partir da fala de P1, o grupo iniciou a busca por possibilidades de ensino desse conteúdo.

P1: No geral, o que mais dá trabalho para ensinar no sexto ano é frações.

(SESSÃO 12, 03/2014)

As sessões que reuniam o grupo geral tornaram-se momentos de partilha de experiências e a compreensão de colaboração foram aparecendo na fala dos participantes, que mostraram preocupação em tornar o trabalho colaborativo, como apresenta a fala de M1 ao relatar sobre o planejamento das atividades sobre frações para os demais subgrupos.

M1: Esse trabalho é feito em conjunto para que haja a colaboração, pois a colaboração é marcada pela ajuda mútua e, sem a ajuda, o grupo dificilmente se constitui como colaborativo. E se já que temos essa ajuda mútua, já fica explícito a questão da confiança estabelecida pelo diálogo. E, nesse trabalho, gostei muito da iniciativa das licenciandas em colaborar na construção das peças do Tangram de EVA.

(SESSÃO 14, 03/14)

As interações dentro do grupo provocaram descobertas que sugiram pela dinâmica realizada na elaboração dos planejamentos em conjunto e os momentos de discussão das 
atividades provocaram os partícipes, levando-os a questionar os seus próprios conhecimentos como também compreenderem a importância do outro na construção de conhecimento. M1 reconhece a importância da discussão em grupo das atividades realizadas em sala durante a elaboração do planejamento sobre noções de frações para o sexto ano do Ensino Fundamental.

M1: Quantos triângulos menores cabem no triângulo médio? Na verdade, no médio cabe duas vezes. Bem, deixa eu pensar.

P1: Quantos menores cabe no médio?

M1: É...

P1: Metade

M1: Deixa eu ver como é aqui. É verdade, metade mesmo. Eles vão sobrepor, bem se é metade, quer dizer que a área desse triângulo (médio) é a mesma do quadrado e a mesma do paralelogramo. Interessante, né?

P1: Bacana! O tempo vai passando, nós vamos trabalhando da forma normal, comum e não vê essas coisas bacanas.

M1: Isso tudo é tempo, quase não temos tempo. Essa atividade da garrafa, algo simples com material descartável, mas eu, como professora, nunca trabalhei com essas atividades, então, eu vim pensar agora. Eu já tinha trabalhado com o tangram, mas só montando figuras e não tinha sentido para mim, ficar montando essas figurinhas: gatinha, coelhinho, ... P1: Qual a relação?

M1: Não tinha e eu queria uma relação com a Matemática.

(SESSÃO 13, 04/14)

Na visão de Sawyer (2003, p. 82), "Colaboração é a criação compartilhada e a descoberta de dois ou mais indivíduos com habilidades complementares interagindo para criar um entendimento partilhado que nenhum deles tinha possuído antes ou poderia ter conhecido por si só”.

Este trabalho possibilitou-nos entender que, por meio da colaboração, os professores seriam capazes de compreender os sentidos e os significados acerca da interação e da colaboração. Essa compreensão, quando realizada em contextos de formação que buscam uma criticidade dos participantes, cria modos de participação que instigam os indivíduos por meio da interação com pares mais experientes.

Cabe destacar que, por se tratar de um grupo envolvendo professores, licenciandos e pesquisadores, os conhecimentos partilhados davam-se pelas experiências vividas em sala de aula e pelas discussões por meio de estudos de textos, nos encontros com o grupo geral também havia possibilidades de compartilhar conhecimentos com outros pesquisadores, assim como também nas reuniões do grupo de pesquisa Formação e Educação Matemática FORMEM, que estava atrelado ao projeto e todos eram convidados a participar.

Nos momentos que o grupo planejava as atividades para serem desenvolvidas em sala de aula foram os que mais identificamos colaboração, pois, como afirma Ibiapina (2008a), colaborar é, além de ajuda mútua, principalmente, objetivo comum. Depois de 
elaborada e discutida a atividade sobre noções de frações com o uso do tangram, M1 mostra que a colaboração também faz parte da ação do grupo ao dizer que iriam, no desenvolvimento da atividade na sala de aula de P1.

M1: Nós vamos com você amanhã e, no dia seis, para trabalharmos frações com tangram e a parte de noções de frações encerra.

(SESSÃO 15, 04/2014)

No ano de 2015, as sessões colaborativas foram retomadas em março, a dinâmica continuava a mesma, primeiramente, o grupo levantava as necessidades dos professores que estavam em sala de aula e, depois, buscava atividades para serem desenvolvidas. A essa altura, o grupo já estava mais avançado em relação à compreensão da pesquisa colaborativa, todos já sabiam os seus papéis, mas o momento era outro e as necessidades ficaram mais refinadas, o grupo ganhou mais autonomia nas suas escolhas e mais poder de decisão em conjunto.

Assim, a colaboração mostra-se nesses momentos de discussão sobre o conteúdo a ser trabalhado, na organização do trabalho a ser desenvolvido em sala de aula, na negociação diante das condições que a escola oferece como se observa nos relatos nas sessões 23 e 24 .

M1: Então, eu estou no oitavo ano, o P1 e o P4 também.

Ps: Todos vocês têm oitavo ano?

P1: Exato. Fica uma coisa só para todos. É bom, porque tem como nós discutirmos.

$[\ldots]$

M1: Então, nós vamos pensar juntos no que vamos trabalhar nesses oitavos em relação à geometria. Podemos pensar algo para o dia 30. Eu pensei em trabalhar aqueles conceitos iniciais e construir com eles com palitinhos de churrasco e bolinhas de isopor. Eles poderiam fazer várias figuras tridimensionais e, depois, passaríamos uma atividade para eles explorarem, ou seja, eles mesmos podem responder a partir de nossos questionamentos. E, a partir daí, trabalharíamos o conceito. Não sei se vocês estão de acordo com isso.

P1: Então, porque, no oitavo ano, no segundo bimestre, é sistema, cálculo algébrico, polinômios, expressões algébricas, espaço e forma, construção de paralelas, perpendiculares, mediatrizes, segmentos com régua e compasso, congruência de triângulos.

M1: Com a construção desses sólidos, com essas bases, nós vamos estar trabalhando com retas [...].

Ps: Vai dar para explorar vários conceitos.

M1: Isso. Eu já tinha olhado essa ementa.

P3: Mas, esse material seria usado como uma introdução, porque ali fala régua e compasso.

P1: Mas, régua e compasso, nós não vamos usar.

P3: Não?

P1: Não, porque os alunos não têm, não chegou o material, a Prefeitura não mandou esse material, não temos nem régua.

(SESSÕES 23 e 24, 04/2015) 
Atender a necessidade do professor é um dos pontos iniciais da formação, pois é a partir das necessidades vivenciadas por eles que devem surgir as demandas de formação. Assim sendo, quando o participante emite uma necessidade, ele também declara uma ação de mudança, visto que ela é sempre justificada.

Para Ibiapina (2008a, p 42), atender essas necessidades do professor por meio de uma formação é "[...] retraduzir as motivações e os objetivos construídos pelo grupo de professores para construção permanente de seu desenvolvimento profissional”. Destacamos um desses momentos, que ocorreu na vigésima sexta sessão.

M1: Então, eu gostaria de trabalhar, na parte de espaço e forma, com sólidos geométricos e figuras planas.

Ps: Mas, você acha que os alunos têm dificuldades nesse conteúdo?

M1: Tem muitos professores que nem trabalham esses dois conteúdos. Eu mesma fico muito amarrada com os outros blocos, números e operações [...]. Agora, o que o P1 falou, no encontro passado, é verdade. Eles querem que nós trabalhemos nos quatros eixos durante o bimestre [...], então, essa atividade, que eu estava pensando, vai atender tanto os sólidos geométricos quanto as figuras planas.

(SESSÃO 26, 06/2015)

Os indícios de colaboração ficam evidentes nas sessões, o engajamento, a partilha de conhecimentos e a negociação fazem-se presentes nos momentos de planejamentos, pois eles são ricos de experiências e, ao aprendermos com o outro, transformamo-nos, como afirma Vygotsky (2000a). A colaboração vai se constituindo quando o grupo se mostra numa ação conjunta por um objetivo único, como no diálogo da $26^{\mathrm{a}}$ sessão.

M1: Pensei que hoje podemos conversar, trocar ideias e, na próxima semana, providenciar os materiais. Uma coisa que eu pesquisei e gostei foi a mesma ideia que a G1 trouxe. Estamos bem conectadas.

Todos: (risos)

P1: Eu acho que nós também estamos bem conectados, porque eu saí de casa pensando justamente nisso. Sabe o que eu pensei, [...] nós podemos fazer a planificação, porque trabalha a figura plana e também espacial. Não é?

(SESSÃO 26, 06/2015)

O processo de colaboração envolve também os conflitos, entretanto, é importante criar um clima democrático para gerenciá-los de forma criativa. Bakhtin (2002, p. 14) afirma que "[...] a palavra é a arena onde se confrontam os valores sócios contraditórios, e, em qualquer momento de sua existência, é de natureza múltipla, pois nela, na palavra coexistem contradições sócio-ideológicas”.

Nessa perspectiva de formação, Ibiapina (2008a) reforça que o conflito pode tornar-se uma ferramenta produtiva, pois dá vida à colaboração. Nesse sentindo, entendemos que os professores atuantes e conhecedores de sua realidade possuem as suas concepções e a 
sua metodologia de aprendizagem, como mostram os fragmentos apresentados a seguir, extraídos da vigésima sétima sessão, durante a elaboração das atividades.

P1: [...] A princípio nós temos o quê? Na minha concepção, que pode ser mudada, claro (risos). Primeiro, nós temos que dar a aula sobre poliedros, explicar a definição, isso antes de manipular o material. Na aula seguinte, nós vamos montar esse material e eu gostaria, no meu caso, não sei o que vocês acham, de usar a relação de Euler para preencher aquela tabelinha, que eu achei o principal, porque é ali que vamos saber se os alunos entenderam mesmo. Então, primeiro, eles reconhecem o que são poliedros e não poliedros, isso nas habilidades a serem desenvolvidas, já fazemos isso na primeira aula. E, depois que compreender os conceitos de poliedros, reconhecer diversos poliedros, os principais, e, na segunda aula, ensinamos essa relação que tem a face, os vértices e as arestas. Os alunos têm que saber isso, e, por último, que é montar.

M1: Eu acho que é o inverso.

P1: O inverso?

M1: É!

P1: Mas, tem que dizer o que é poliedro, o aluno vai montar o que, sem saber. Primeiro, o aluno tem que saber o conceito, senão ele não vai montar. $\mathrm{O}$ que ele sabe?

(SESSÃO 27, 05/2015)

Nessa fala P1 apresenta uma proposta que foi muita discutida por ser uma aula tradicional $^{1}$ do ensino de Matemática, em que, primeiramente, o conceito é apresentado, retirando do aluno a autonomia para construção do seu próprio conhecimento. Esse conflito de ideias vai ao encontro dos estudos de Magalhães (2009), que ressalta que colaborar envolve situações tensas que trazem conflitos fundamentais para um aprofundamento de questões problemáticas, entretanto, por meio dessas questões, são propiciadas transformações relevantes nos modos de pensar e agir dos participantes em um trabalho na perspectiva da colaboração.

Nesse sentido, Ibiapina (2008a) afirma que a colaboração traz contribuições não apenas nos estudos de teorias, que podem ou não ser aplicadas, mas “[...] entendimentos que levem a compreensão das condições objetivas do trabalho docente e a articulação imediata entre a teoria e a pratica”. (p. 33). Após a elaboração e o desenvolvimento do planejamento sobre os sólidos, o grupo decidiu trabalhar com volume, como mostra o diálogo a seguir.

P1: Eu queria conversar com vocês, saber o que vocês acham, se seria bom nós trabalharmos com volume, o que seria cubo e paralelepípedo, porque eu acho que tem bastante campo para nós explorarmos. Ou, sistemas de equação do primeiro grau, polinômios ou expressões algébricas.

G2: Talvez seja melhor volume, para continuidade no trabalho que vem sendo feito.

P1: O que vocês acham? Eu estou trazendo o que nós precisamos lá.

${ }^{1}$ É uma aula expositiva em que é transmitido aquilo que julga ser importante, seguido de exemplos de aplicação e, depois, exercícios (D'AMBRÓSIO, 1989). 
(SESSÃO 29, 06/2015)

Nesse diálogo, compreendemos que o grupo estava superando a cooperação e ganhando autonomia, possibilitando que todos tenham vez e voz em todos os momentos. Entendemos que os momentos de discussões sobre a elaboração das atividades, o uso dos pronomes, a gente, nós e todos, tem sido recorrente e, de acordo com os indicadores analíticos produzidos para as análises desse eixo, as suas ações podem ser relacionadas à colaboração.

Consideramos que, no decorrer das sessões, os professores foram compreendendo a dinâmica da pesquisa colaborativa e os seus papéis, ao reportar-se ao trabalho de formação continuada que frequentavam, $\mathrm{P} 1$ faz fortes críticas ao formato vivenciado naquele momento:

Ps: Esse pessoal que vai lá. Qual a função deles, mesmo? É tentar ajudar a melhorar essa aprendizagem. Esse índice?

P1: É. Só que eles acham que vai melhorar cobrando.

Ps: E o que eles fazem?

P1: Não sei, eles ficam trancados em uma sala, querem ver planejamento, pegam caderno de aluno para ver se está batendo.

Ps: Mas, eles não apresentam nenhuma possibilidade?

P1: Tem a formação continuada que junta todo mundo e você fica lá calado, tendo que ouvir.

(SESSÃO 30, 06/2015)

Contrapondo esse formato, a proposta de formação com uso da pesquisa colaborativa proporcionou, por meio de suas ferramentas, uma interação colaborativa entre participantes e a necessidade da partilha, como afirma M1.

M1: Porque esse planejamento de forma diferenciada, a minha conclusão é que ele só é possível a partir de um grupo. [...] então só deu certo por causa do coletivo, pelo grupo. O professor sozinho é complicado.

(SESSÃO 30, 03/2015)

Nas últimas sessões, ficou mais evidente essa contribuição das sessões em que os professores relataram as dificuldades que tiveram em entender que eles estavam envolvidos no projeto e que a atuação era na condição de protagonistas, mostraram que, de fato, houve momentos de colaboração e ela foi peça fundamental para o desenvolvimento do trabalho.

M1: Então, por isso que, no início, nós começamos com dinâmicas, leituras para estimular a fala, esse foi um desafio. Porque não existe hierarquia, mas existem os papéis e essa era outra dificuldade também, era deixar isso claro, não há hierarquia, mas existem os papéis.

P1: É isso, não tem hierarquia, mas tem papel, e tem que respeitar o papel do colega, porque o fato de não ter hierarquia não significa que uma pessoa que tem mais experiência, sabe que está falando, por exemplo, eu vou fazer um trabalho com o $\mathrm{P}_{3}$, ele está lá na escola, ele conhece a escola, ele sabe o 
que está falando, ainda que não haja hierarquia tem que entender o papel dele. Se ele falar, melhor assim, pronto, porque ele vive lá.

(ENTREVISTA COLETIVA, 03/2015)

Nesse sentido, Ibiapina (2009) aponta que é necessário que se parta da realidade concreta, vida vivida pelos partícipes da investigação, ou seja, do contexto real e não apenas do ideal, para que não haja confusão na interpretação da ação dialética com a pragmática, em que a pragmática visa apenas aos resultados imediatos de compreensão da prática pela prática, enquanto a dialética objetiva a transformação da atividade concreta.

Nesse contexto de trabalho, buscamos, na pesquisa colaborativa, instrumento possibilitador de encontros colaborativos produtivos, que proporcionaram aos participantes mudança de postura e desejo em resolver conflitos, partilhar conhecimentos e experiências, ampliando o significado de suas ações. Assim, no trabalho colaborativo, as ações não visam à transformação ou ao desenvolvimento apenas de um indivíduo em particular, mas da totalidade (IBIAPINA, 2009). Ao apresentarmos as sessões, evidenciamos que houve momentos de colaborações, observamos que os participantes, ao longo das sessões colaborativas, foram ampliando a compreensão do conceito de colaboração e fazendo dele parte de suas ações no grupo.

\section{Algumas Considerações}

No desenvolvimento deste trabalho, buscamos compreender o movimento de colaboração entre os participantes de uma proposta de formação continuada desenvolvida por meio da metodologia da pesquisa colaborativa. A colaboração foi ocorrendo no decorrer das sessões, pois cada um tinha a sua função, mas todos com objetivos e motivos comuns. Com isso, as atividades elaboradas em grupo e desenvolvidas em sala de aula mostraram que era possível solucionar alguns problemas de aprendizagem, mesmo com atividades simples e pouco recurso.

Percebemos, pela fala dos participantes, que o estudo teórico influenciou na realização e no desenvolvimento de atividades elaboradas em grupos e que o fato de planejarem junto seria possível em todas outras atividades realizadas em sala de aula, fazendo com que os participantes percebessem que é plausível ter uma prática colaborativa.

A possibilidade que o projeto propiciou aos participantes da pesquisa, fez com que eles olhassem a riqueza que há em sala de aula e o rico material com que trabalham. Como também, a grande oportunidade que tiveram de compartilhar seus conhecimentos e experiências com futuros professores também participantes do projeto.

Notamos ainda que houve mais conhecimentos e experiências didáticas do que de conteúdos matemáticos, pois os conceitos matemáticos trabalhados eram de domínio dos 
participantes. Assim sendo, as discussões ocorreram mais em torno das situações didáticas, ou seja, sobre como tornar o conceito compreensível para os alunos e, para isso, o grupo optou por utilizar materiais didáticos manipuláveis, para que os alunos construíssem os conceitos abordados, sendo esses momentos de grande aprendizagem para os participantes, principalmente para P1 que não tinha essa prática em suas aulas.

Com isso, a formação realizada no projeto OBEDUC, por meio da metodologia da pesquisa colaborativa, tornou-se uma oportunidade de formação e pesquisa para todos os participantes. Esse formato para realizar-se uma formação criou vínculo e foi além das produções que gerou, foi uma abordagem de formação contínua, que atingiu a vontade de ser professor do graduando, do professor de ser pesquisador e de cruzar os caminhos da universidade e da escola.

\section{Referencias}

ABRANTES, P; Ponte J. P. Professores de Matemática: Que formação? In Actas do Colóquio sobre o Ensino da Matemática: Anos 80 (pp. 269-292). Lisboa: SPM. 1982. ALBUQUerQue, L. C. Avaliação da Aprendizagem: concepções e práticas do professor de matemática dos anos finais do ensino fundamental. Dissertação (Mestrado em Educação). UnB/DF. 2012.

ANDRADE, J. A. A. O Estágio na Licenciatura em Matemática: um espaço de formação compartilhada de professores. Tese (Doutorado em Educação) UFSCar/SP, 2012.

BAKHTIN, M. M. Estética da criação verbal. São Paulo: Martins Fontes, 2002.

CAMPos, S. G. V. B. Trabalho de Projetos no Processo de Ensinar Aprender Estatística na Universidade. Dissertação (Mestrado em Educação). UFU/MG. 2007.

CANDAU, V. M. F. A formação continuada de professores: tendências atuais. In: REALI, A. de M. R.; MiZUKAMI, M. da G. N. (Org.). Formação de professores: tendências atuais: São Carlos: EDUFSCar, 1996. p. 139-152.

CANDAU, V. M. F. Formação continuada de professores: tendências atuais. In: Candau, V. M. F. (Org.). Magistério: construção cotidiana. Petrópolis: Vozes. p. 5168. 1997.

COElho, M A. V. M. P. Os Saberes Profissionais dos Professores: a problematização das práticas pedagógicas em estatística mediadas pelas práticas colaborativas. Tese (Doutorado em Educação) - Universidade Estadual de Campinas, Unicamp, Campinas-SP, 2010. 
COSTA, M. L. C. Colaboração e Grupo De Estudos: perspectivas para o desenvolvimento profissional de professores de matemática no uso de tecnologia. Dissertação (Mestrado em Ensino de Ciências e Matemática) UEPB/PB. 2011.

DEMAILLY, L. C. Modelos de formação contínua e estratégias de mudança. In: NÓVOA, A. Os professores e sua formação. Lisboa. Instituto de Inovação Educacional, p. 139-158.1992.

DESGAGNÉ, S. Le concept de recherche collaborative: l'idée d'un approchement entre chercheurs universitaires et praticiens enseignants. Revue des Sciences de L'Éducation, v. 23, n.2, p.371-393,1997.

DESGAGNÉ, S. O conceito de pesquisa colaborativa: a ideia de uma aproximação entre pesquisadores universitários e professores práticos. Revista Educação em Questão. Natal, v. 29, n. 15, mai/ago 2007, p. 7 - 32.

FERREIRA, A. C. Metacognição E Desenvolvimento Profissional De Professores De Matemática: uma experiência de trabalho colaborativo. Tese (Doutorado em Educação) - Universidade Estadual de Campinas, Unicamp, Campinas-SP, 2003.

FERREIRA, A. L. Possibilidades e realismo crítico da Pesquisa e da formação: a colaboração entre pesquisadores e professores. IBIAPINA, I. M. L. de M.; RIBEIRO, M. G.; FERREIRA, M. S. (Org.). Pesquisa em educação: múltiplos olhares. Brasília: Líber Livros, 2007.

FIORENTINI, D. Pesquisar práticas colaborativas ou pesquisar colaborativamente? In: BORBA, M. C.; ARAÚJO, J. L. (Org.). Pesquisa qualitativa em Educação Matemática. Belo Horizonte: Autêntica, 2004. p. 47-76.

GAMA, R. P. Desenvolvimento Profissional com apoio de Grupos Colaborativos: o caso de professores de matemática em inicio de carreira. Tese (Doutorado em Educação) - Universidade Estadual de Campinas, Unicamp, Campinas-SP, 2007.

GOMES, E. B. Aprendizagem Docente e Desenvolvimento Profissional de Professores de Matemática Investigação de Experiências Colaborativas no Contexto da Amazona Paraense. Tese (Doutorado em Educação em Ciências e Matemáticas). Rede Amazona de Educação em Ciências e Matemática REAMEC, Bélem/Pará, 2014.

GRINKRAUT, M. L. Formação de Professores Envolvendo a Prova Matemática: um olhar sobre o desenvolvimento profissional. Tese (Doutorado em educação matemática). PUC/SP. 2009.

ISSN 2526-2882

$* 82 *$ 
IBIAPINA, I. M. L. de M. Pesquisa Colaborativa: investigação, formação e produção de conhecimentos. Brasília: Liber Livros, 2008a.

I. M. L. de M.; MAGalhães, M. C. Pesquisar e colaborar na formação contínua de professores: modos de agir. In: Colóquio Internacional da AFIRSE. João Pessoa: Em. UFRN, 2009.

I. M. L. de M. A conquista: pesquisadores e professores pesquisando colaborativamante. In: JUNIOR, Eduardo Loureiro; IBIAPINA, I. M. L. de M. (Org.). Videoformação, reflexividade crítica e colaboração: Pesquisa e formação de professores. Belo Horizonte: Autêntica. 2008b.

IMBERnÓN, F.. Formação Continuada de Professores. Tradução Juliana dos Santos Padilha. - Porto Alegre: 120p. 2010.

KEMMIS, S. Critical reflection. WINDEEN, M; ANDREWS, I. Staff development for school improvement. Philadelphia, USA: Falmer Press, p. 73-90. 1987.

MAGAlHÃES, M. C. C. Pesquisa Crítica de Colaboração em projetos de formação contínua em contextos escolares: colaboração na pesquisa e na ação. In: BALDI, E. M.; FERREIRA, M. S.; PAIVA, M. (Org.) Epistemologia das ciências da educação. Natal: Ed. UFRN, 2009a. p. 227-243.

M. C. C. O método para Vygotsky: A Zona Proximal de Desenvolvimento como zona de colaboração e criticidade criativas. In: SCHETTINI, R. H. et al (Org). Vygotsky: Uma (re) visita no Século XXI. São Paulo: Andross, 2009b, p. 5378.

Maria Cecília Camargo; OLIVEIRA, Wellington. A colaboração crítica como uma categoria de análise da atividade docente. In: MAGALHÃES, Maria Cecília Camargo; FIDAlgo, Sueli Salles. (Org.) Questões de método e de linguagem na formação docente. Campinas, SP: Mercado de Letras, 2011.

MORAN, Seana; JOHN-STEINER, Vera. Creativity in the making: Vygotsky contemporary contribution to the dialectic of development and creativity. In: SAWYER, R. Keith. Creativity and development. E. U. A Oxford: University Press, 2003. p. 1-54.

NÓVOA, A. Concepções e práticas da formação contínua de professores: In: Nóvoa A. (Org.). Formação contínua de professores: realidade e perspectivas. Portugal: Universidade de Aveiro. 1991.

OLIVEIRA, W. A colaboração crítica no desenvolvimento de uma atividade de formação de professores a distância. Tese de Doutorado. Programa de Pós- Graduação em Educação, Pontifica Universidade Católica, São Paulo, 2009.

ORFAO, R. B. Professores de Matemática em um Grupo de Estudos: uma investigação sobre o uso de tecnologia no ensino de funções ISSN 2526-2882 
trigonométricas. Dissertação (Mestrado em Educação Matemática. UNIBAN/SP. 2012.

PEREIRA, D. G. Um Estudo da Reta no Ensino Médio Utilizando Trajetórias Hipotéticas de Aprendizagem. Dissertação (Mestrado em Educação Matemática). PUC/SP. 2011.

TRALDI JÚNIOR, A. Formação de Formadores de Professores de Matemática: identificação de possibilidades e limites da estratégia de organização de grupos colaborativos. Tese (Doutorado em Educação Matemática). PUC/SP, 2006.

VIGOTSKI, L. S. A Formação Social da Mente. São Paulo: Martins Fontes, 2000a

, L. S. Psicologia concreta do homem. Educação \& Sociedade, Campinas: CEDES, $\mathrm{n}^{0}$ 71, pp. 21-44, 200ob.

L. S. A construção do pensamento e da linguagem. São Paulo Martins Fontes, 2001.

\section{Biografia Resumida}

Adriana Fatima de Souza Miola: Graduada em Licenciatura Plena em Matemática (UFGD). Mestrado e Doutoranda em Educação Matemática (UFMS) com Doutorado Sanduíche na Universidade de Lisboa sob a Orientação do Prof. Dr. João Pedro da Ponte. Docente no curso de Matemática da Universidade Federal da Grande Dourados (UFGD) Líder do Grupo de Pesquisa Tecnologias na Educação Matemática GPTEM/CNPq.

e-mail: adrianamiola@ufgd.edu.br

Patricia Sandalo Pereira: Graduada em Ciências - Habilitação Plena em Matemática pela Universidade Federal de Uberlândia (UFU). Doutora e Mestre em Educação Matemática pela UNESP - Rio Claro/SP. Professora Associada da Universidade Federal de Mato Grosso do Sul (UFMS). Líder do grupo de pesquisa Formação e Educação Matemática (FORMEM).

e-mail: patricia.pereira@ufms.br 